chluroform and examined, and the tracheotomy wound was freely enlarged; an examination showed that at the level of the tracheal opening there was a dense collar of cicatricial tissue encroaching on the lumen of the trachea. Tic trachea at the same point appeared to bend backwards, the part below forming an angle with the part above the obstruction collar, as shown in Fig. 2 The

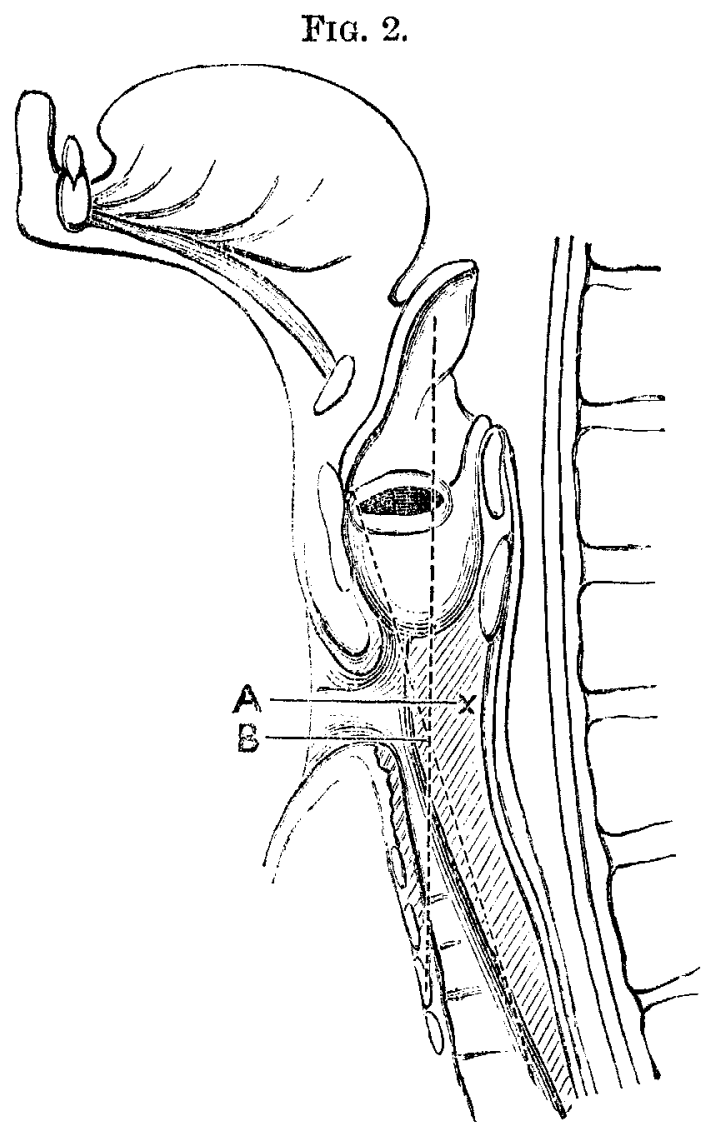

A, The cicatricial tissue in this case extended a long way down the back and silles of the trachea.

cicatricial tissue was dissected away very freely, together with the lining of the tracheotomy opening. A large trasheotomy tube was then introduced. Intubation was recommenced on Feb. 27th; the largest size but one was left in. It was coughed out next day, but although the tracheal wound was plugged the patient could breathe comfortabiy through the mouth. The tracheal wound was allowed now to heal; intubation was repeated every few days until May 7th, when the child developed measles. At this period phonation (an extremely deep note) was just possible with great effort. During the attack of measles it was found necessary to keep the intubation tube almost constantly in. Intubation was frequently done during June, and on July 14th the child was sent home, as it was thought he might be intubated as an out-patient. $\mathrm{He}$ returned in three days after his discharge, a tube was put in, and he wore this at home for ten days, taking ordinary foad as usual. The tube was now left out sixteen days, and then again worn for ten days; it was then taken out and replaced and retained for another week. During the last two months the mother neglected to bring the child to the hospital. By special request the mother brought the child to see us on Nov. 23rd. There was then some stridor and dyspnoea on exertion. Phonation only by great effort.

Remarks. - This case shows the great difficulty that may be experienced in the restoration of natural breathing. Considering the extensive sloughing of the tracheal wound and the necrosis of portions of the tracheal rings, it cannot be wondered at that an extensive formation of cicatricial tissue arose. Some kinking of the trachea opposite the trasheal opening is, we believe, of not infrequent occurrence, and this, combined with the cicatricial stricture, made the case remarkably intractable. Much time was wasted in the treatment by not attending to the lesson that ought to have been learnt from the first case--namely, where intubation is not at once satisfactory, to explore for and remove, as far as possible, all mechanical obstruction. We were unwilling, after the extensive sloughing that had occurre , to meddle with the wound if we could avoid it. This ce se must be considered as still under treatment. $\mathbf{T}$ ' ere nast be as much necessity for constant dilatation as in a bad cicatricial stricture of the urethra. We believe, however, if the mother had not neglected to bring the child for the last two months it would now have been in a more satisfactory condition than he is at present. The parents unfortunately considered the child so well as not to require further treatment.

$$
\text { (To be concluded.) }
$$

\section{CHOLERA IN NORTHERN SYRIA.}

\section{BY JOHN WORTABET, M.D.,}

CORRLSPONDING MFYUER OF TIEE EPIDEMIOLOCICAT, SOCIETY OF LONDON, ANI OF THE MEDICO-CHIRURGICAL SOCINTY OF EDINISURGH.

THE present epidemic of cholera in the north of Syria originated from Mesopotamia, where it was well known to have been for some time previously. It appears to have been imported to Aleppo by a nomadic tribe of Bedouins from a point on the Euphrates about fifty miles from that city, and where its first appearance was oflicially recognised about Sept. 13th. From this point it spread northwards, implicsting Killis, Aintab, Berejeck, Orfa, and Marash ; and to the south, where the principal places attacked were Hamath, Antiocl, and Homs. The informa. tion about the former of these regions is too meagre and unreliable to enable me to give any details, and it is quite possible that the infection may have been brought to some of the places mentioned directly from some Mesopotamian focus. But there can be no doubt as to the extension of the disease from Aleppo southwards, and it is with this that I wish to deal in the present communication. This extension took place in spite of the so-called cordons and quarantines which the Government imposed between infected and sound spots. And yet it is equally certain that, to the unusually vigorous measures of this kind taken by the governors of Damascus, Beyrout, and Mount Lebanon, isolating these tracts from Aleppo, Hamath, Homs, and Antioch, the immunity, so far, of these places is due. It remains, however, to be seen whether they will succeed in warding off the disease permanently, or whether they will be useful only in retarding its approach until the cold weather sets in, when it is hoped its violence may be mitigated. That cordons and land quarantines carried out effectually, and under scientific and favourable conditions, will prevent the diffusion of cholera and destroy it on its way, has, I think, been satisfactorily proved this year in the case of the Hejaz pilgrims, who were put into quarantine at distant spots from any inhabit. able land, and from which escape was impossible. Those pilgrims coming from Mecca, Medina, and Jeddah, and bearing with them the disease, were cradually freed from it during their forced detention on the waste shores of the Red Sea; and it was thus that, so far as can be seen, Egypt, Syria, and Turkey were saved from what seemed at one time to be an inevitable fate. The land pilgrims coming from Mecca to Damascus by short stares, isolated through an open and uninhabited route, and taking some weeks on the way, became free of it, and returned to that city in perfect heaith. But it is far different in a populons land where the means of communication are sogreat, where cordons have been repeatedly tried and always failed, and where, on the other hand, the value of public and private sanitation has been proved beyond all doubt. The simpler hygienic means, such as cleanliness of dwellings and streets, prevention of the sale of unripe and rotten fruits and unwholesome food, \&c., were probably ordered and partially executed in the infected places by the local authorities; but in the equally important matters of drains, gutters, and cesspools, where more scientific and drastic measures are called for, it is to be feared that very little, if anything, was done. Still, it appears that the violence of the present epidemic in Aleppo is very considerably less than that of previous visita tions. This is probably due to improved methods of sanitation, while it is certain that in Aleppo there had been up to Oct. 26th no case of cholera among the Europeans and better class natives, whose lives and surroundings were made as unfavourable to infection as possible.

Aleppo is a city of Northern Syria, having an estimated population of about 100,000 , and lies in a plain 1600 feet above the sea-level. Its water-supply comes from a small stream which is used up in irrigating the gardens, and its drinking water comes from a spring near Aintah, which is 
carried in a covered conduit. On the appearance of cholera about Sept. 12th, and up to the 22 nd of that month, no official bulletins were issued, but the officer of lealth estimated the fatal cases at 21 . A local sanitary commission was then appointed, and the following weekly returns are drawn up from its daily reports. It is generally believed, however, that the rate of mortality is very much understated, while a few hold that it is somewhat above the real number of deaths. The number, therefore, is only approximately true, and is given as a fair idea of the natural course and duration of the epidemic in the East, and especially as regards its periods of rise, height, and decline. The last accounts from that city show at this date (Nov. 26th) that the epidemic has entirely ceased.

Estimated cases of death from Sept. 13th to 22nd Sept. 23rd to 29 th (say, second week) ... , 30th to Oct. 6th (third week)

Oct. 7th to "13th (fourth week)

14th to "20th (fifth week)

2 lst to ,2 28th (sixth week)

29 th to Nov, 4th (seventh week)

Nov. 5th to ", 11th (eighth week)

"12th to ,, 18th (ninth week)

\section{Total}

Hamath, a town of about 40,000 inhabitants, lies about three days' journey south from Aleppo, and is built on the two sides of the Orontes, which, taking its rise from a point near Baalbec, runs due north, passes about a mile west of Hom?, and at Hamath turns to the west, supples Antioch with its waters, and empties itself into the bay of the ancient Seleucia. Its elevation above the level of the sea is a little more than $1000 \mathrm{ft}$. Though the official records give Oct. 15th as the earliest date of the appearance of cholera in it, and thus a heavy mortality for the first week, it is more likely that it began come days before it was recognised and officially announced, and that its first cases were few. The following is the record which I have been able to obtain from the official papers :-

First week

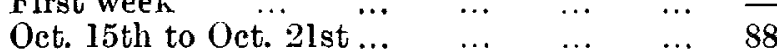

", 22nd to ," 28th ... $\quad \ldots \quad \ldots, \quad \ldots \quad 303$

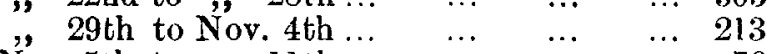

Nov. 5th to , 11th ...

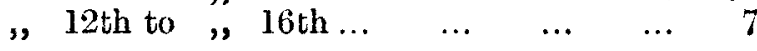

Total

687

From Nov. 12th to this date (Nov, 26th) I have been unable to obtain any definite information, but the number of daily deaths has been gradually diminishing, and the epidemic there is said now to have ceased.

Of Antioch, whose population is estimated at 12,000 , the records are as follows :-

$$
\begin{aligned}
& \text { Oct. } 20 \text { th to Oct. } 26 \text { th ... , .. } \quad \ldots \quad \ldots \quad 22 \\
& \begin{array}{llllll} 
& \text { 27th to Nov. 2nd ... } & \ldots & \ldots & \ldots & 159
\end{array}
\end{aligned}
$$

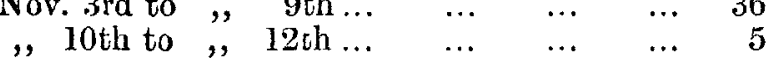

This is evidently very imperfect, but $I$ give it for what it is wortb.

The following are the returns from Homs, a town of 25,000 inhabitants and a day's journey south of Hamath :-

$\begin{array}{ccccccc}\text { Oct. 27th to Nov. 2nd } & \ldots & \ldots & \ldots & 63 \\ \text { Nov. 3r. to } & \text { 9th } & \ldots & \ldots & \ldots & 234 \\ \text { " 10th to } & , & \text { 16th } & \ldots & \ldots & \ldots & 169 \\ \text { " 17th to } & , & 21 \text { th } & \ldots & \ldots & \ldots & 130 \\ & & & & & & \overline{596}\end{array}$

En résumé, it appears that the epidemic has almost entirely ceased in Aleppo after a duration of about ten weeks, the third, fourth, and fifth showing the highest number of deaths. A late telegram from Hamath gives the same news, though it is quite possible that fresh cases may still break out, as may be observed in the eighth and ninth weeks of the march of the disease in Aleppo, and that a slight rise during the period of decline may be an ordinary phenomenon in the history of cholera epidemics. If, however, the duration of the disease in Hamath, Homs, and Antioch is to be short, this may be due to an unusually long storm of rain and cold which has overrun the whole of Syria since the 15th of this month to this date, or to the unusual severity of the epidemic in those places, which has exbansted itself sooner than it did in Aleppo, where the relative rate of mortality was much milder. Judging from previuus cbolera visitations in Syria, it seems that the ordinary duration of an epidemic is rarely less, if ever, than ten weeks, and it looks very much as if it had, when the population is stationary, a definite course to run, like a case of typhoid fever and most of the acute diseases. How much this has to do with the life history of the cholera bacillus in o given place is difficult to say in our present state of knowledge. The whole coast of Syria and the whole of its gouthern part are so far intact, and I do not know how this can be accounted for except by believing that the measures of isolation taken by the authorities have been unusually rigid, and thus effectual in warding off the spread of the disease to these parts up to this date.

Beyrout, Nov. 20th, 1890.

\section{CHOLECYSTOTOMY FOR GALL-STONES, PERFORMED ON THE STRENGTH OF'} SYMPTOMS WITHOUT PHYSICAL SIGNS.

By A. W. MAYO ROBSON, F.R.C.S.,

HONORARY SURGEOY TO THE LEEDS GIENERAL FFIRMARY, PROFESSOR OF SURGERY IN THE YORKSHIRE COLIEGS ANA EMAMLAR IN THE VICTORIA VXIVERSIIY.

ON Oct. 25th of last year I had the honour of reading before the Clinical Society of London a paper based on fourteen cases of cholecystotony. Since that time I have performed the operation nine times without a death, making in all twenty-three cases. In my former paper I gave brief histories of five cases operater upon on the strength of symptoms alone. I have now to add to that series two more cases, notes of which I now give.

Mr. P. B-, aged twenty-nine, residing at Wyke, near Bradford, was sent to see me by my friend Dr. Dearden early in June of last year, when he gave the following history :- He had been quite well up to tweive months ago, when he was seized whilst at work with a sudden attack of severe pain on the right side of the abdomen just below the ribs, which compelled him to return home. The attack lasted for several hours. No jaundice followed, and he was able to return to his duties in a day or two. Ever since that time he had been subject to similar attacks, but on no occasion had he been jaundiced, and he had never noticed any swelling in the region of the liver. The attacks did not recur periodically, he having had once an interval of a month without an attack, whilst on other occasions he would have several in a week. On several occasions the spasms had come on when he was in bed. The attack which he had just previously to admission, lasted six hours. At no time had the motions been clay coloured or the urine specially dark. He was admitted to the infirmary on June $6 \mathrm{th}$, in order that he might be watched for a time, but beyond having several attacks of pain of a similar character no physical signs were noticed. On June 19th cholecystotomy was performed. The gall-bladder was found to be small, and lying well under cover of the liver. One gall-stone was found loose in the gall-bladder, and five others were removed from the cystic duct by means of forceps within, aided by fingers on the outside of the duct. The gall-bladder was so far from the surface that the lower edge of the incision could not be brought to the parietal peritoneum, bence the omentum was made use of to shut out the general peritoneal cavity. This was effected by bringing up the right border of the omentum, stitching it to the incision in the gallbladder and then to the parietal peritoneum. A drainagetube was inserted into the gall-bledder, and bile commenced to flow as soon as the operation had been completed. in June 25th the drainage-tube and sutures were removed. On July 4th the discharge had diminished considerably. On the 12 th the wound had almost healed, and on the 26th it had perfectly closed. The patient was seen in September, when he was looking and feeling perfectly well, and said that he had not had an attack of pain since the operation.

Mr. $R$ - aged fifty, was sent to see me by my friend, Dr. Britton of Harrogate, in April of last year. He gave the history of having been perfectly well up to June, 1889 , when he had a severe attack of pain in the region of the 